\title{
"The Water of Cure" by Alhaji Abubakar Imam as an example of Hausa early fiction
}

\section{A. V.Lyakhovich}

St. Petersburg State University, 7-9, Universitetskaya nab., St. Petersburg, 199034, Russian Federation

For citation: Lyakhovich A. V. "The Water of Cure" by Alhaji Abubakar Imam as an example of Hausa early fiction. Vestnik SPbSU. Asian and African Studies, 2018, vol. 10, issue 1, pp. 104-117. https://doi. org/10.21638/11701/spbu13.2018.109

The 1930-s are known as a turning point in the history of Hausa literature of Northern Nigeria. It was a time during which a new form of creative writing, prose fiction, emerged. The present article analyzes one of the first creative works of Hausa literature - "The Water of Cure" by Alhaji Abubakar Imam. Particular focus is given to the genre and compositional characteristics of the work under discussion; main features of key characters are also examined. In conclusion, the genre specificity of the work is established.

Keywords: fiction, Northern Nigeria, Water of cure, Alhaji Abubakar Imam.

The 1930-s are known as a turning point in the history of Hausa literature of Northern Nigeria. It was a time during which incipient processes took place that later evolved into a type of creativity new for Hausa environment, namely fiction and narrative literature. The present paper intends to analyse one of the first works of Hausa fiction, «The Water of Cure» (Ruwan Bagaja) by Alhaji Abubakar Imam.

Peculiarities of genre and composition specific to «The Water of Cure» are mostly due to there being two plots, or storylines, obviously gleaned from Arabic and European folklore. The first plot seems to have a lot in common with the Arabic «The History of Gharib and His Brother Ajib» [2]. Not only does a comparison of the common motifs found in those texts shed light on their apparent likelihood, it also reveals their similar narrative sequences. Some of those are contained in the table below:

\begin{tabular}{|l|l|l|}
\hline \multicolumn{1}{|c|}{ Motifs } & \multicolumn{1}{|c|}{$\begin{array}{c}\text { The History of Gharib and } \\
\text { His Brother Ajib [2] }\end{array}$} & \multicolumn{1}{c|}{ The Water of Cure [1, p.8] } \\
\hline $\begin{array}{l}\text { Designation of } \\
\text { the protagonist's } \\
\text { father as a } \\
\text { person of high } \\
\text { social standing }\end{array}$ & $\begin{array}{l}\text { There was once in olden time a King of might, } \\
\text { Kundamir hight, who had been a brave and } \\
\text { doughty man of war, a Kahramán, in his day, } \\
\text { but was grown passing old and decrepit. }\end{array}$ & $\begin{array}{l}\text { My father was the chief malam in the } \\
\text { court of the Emir... He was a person } \\
\text { considerably advanced in years... }\end{array}$ \\
\hline $\begin{array}{l}\text { Appearance of } \\
\text { the antagonist }\end{array}$ & $\begin{array}{l}\text { Now it pleased Allah to vouchsafe him... a son, } \\
\text { whom he named Ajíb. }\end{array}$ & $\begin{array}{l}\text { As no sons of his own had been given } \\
\text { him, malam adopted a boy called Sa- } \\
\text { kimu... }\end{array}$ \\
\hline
\end{tabular}

() Санкт-Петербургский государственный университет, 2018 


\begin{tabular}{|c|c|c|}
\hline Motifs & $\begin{array}{l}\text { The History of Gharib and } \\
\text { His Brother Ajib [2] }\end{array}$ & The Water of Cure $[1, p .8]$ \\
\hline $\begin{array}{l}\text { The antagonist's } \\
\text { destructive } \\
\text { conduct }\end{array}$ & $\begin{array}{l}\text { But his skill in weapons made him grow up a } \\
\text { stubborn tyrant and a devil arrogant, using to } \\
\text { ride forth a-hunting and a-chasing amongst a } \\
\text { thousand horsemen and to make raids and raz- } \\
\text { zias upon the neighbouring knights, cutting off } \\
\text { caravans and carrying away the daughters of } \\
\text { Kings and nobles... }\end{array}$ & $\begin{array}{l}\text { Having gained trust in his own physi- } \\
\text { cal prowess the youth made it a habit } \\
\text { of haunting highways and robbing } \\
\text { passers-by. }\end{array}$ \\
\hline $\begin{array}{l}\text { Father's } \\
\text { prohibition }\end{array}$ & $\begin{array}{l}\text {...wherefore many brought complaints against } \\
\text { him to his father, who cried out to five of his } \\
\text { slaves and when they came said, "Seize this dog!" } \\
\text { So they seized Prince Ajib and, pinioning his } \\
\text { hands behind him, beat him by his father's com- } \\
\text { mand till he lost his senses; after which the King } \\
\text { imprisoned him in a chamber so dark one might } \\
\text { not know heaven from earth or length from } \\
\text { breadth; and there he abode two days and a night. }\end{array}$ & $\begin{array}{l}\text { His father forbade him this, yet Sa- } \\
\text { kimu would still misbehave. And so } \\
\text { the malam ruled to have him cap- } \\
\text { tured. }\end{array}$ \\
\hline Patricide & $\begin{array}{l}\text { So Ajib bore with his father for ten days, at the } \\
\text { end of which he went in to him as he slept by } \\
\text { night and smote his neck. }\end{array}$ & $\begin{array}{l}\text {...He took a battle sword and at night } \\
\text { entered his father's chamber [where] } \\
\text { he chopped off his father's head ... }\end{array}$ \\
\hline Prophetic dream & $\begin{array}{l}\text { "I saw my father standing before me, with his } \\
\text { yard uncovered, and there came forth of it a } \\
\text { thing the bigness of a bee, which grew till it be- } \\
\text { came as a mighty lion, with claws like hangers. } \\
\text { As I lay wondering at this lo! it ran upon me } \\
\text { and smiting me with its claws, rent my belly in } \\
\text { sunder..." }\end{array}$ & $\begin{array}{l}\text { In front of him [Sakimu] his mur- } \\
\text { dered father stood towering. From his } \\
\text { father's perineum something smallish } \\
\text { fell out, not exceeding a date stone } \\
\text { in size, and began to swell and upon } \\
\text { reaching the size of a lion informed } \\
\text { Sakimu that it was going to kill him. }\end{array}$ \\
\hline $\begin{array}{l}\text { Interpretation of } \\
\text { the dream }\end{array}$ & $\begin{array}{l}\text { "O mighty King, this dream pointeth to one } \\
\text { born of thy sire, between whom and thee shall } \\
\text { befal strife and enmity, wherein he shall get the } \\
\text { better of thee: so be on thy guard against him, } \\
\text { by reason of this thy vision". }\end{array}$ & $\begin{array}{l}\text { "A boy will be born in your house- } \\
\text { hold. His mother will be one of the } \\
\text { wives of the deceased. He will murder } \\
\text { you". }\end{array}$ \\
\hline
\end{tabular}

The motifs gleaned from «The History of Gharib and His Brother Ajib» given in the table above present only a part of borrowings introduced by Alhaji Abubakar Imam. There are some other elements of content in «The Water of Cure» that were adopted by Hausa author. In particular, the following traces of Arabic narrative can be identified: persecution of the protagonist's mother, her deliverance, a woman's coming across a noble man, who marries her and brings up the young protagonist. At the same time, the texts under consideration differ significantly in their content, concerning firstly the motif of the boy's adoption.

"The Water of Cure" contains also the starting point of another plot, viz. a story about water of life, which can apparently be traced back to European folklore (cf. for instance the story entitled «The Water of Life» from the collection of the Brothers Grimm). We did not find in Hausa literature (both oral and written) the motif of a magic potion to cure any disease, such as «water of life». There are Hausa tales that incorporate the image of so called "ruwan bagaja", expression which Abubakar Imam uses for his "water of cure", how- 
ever in tales "ruwan bagaja" does not appear as a healing treatment [4]. Arabic folklore contains the motif of an abstruse and incurable disease, which affects a king or a king's daughter. The cure may consist in the necessity for the diseased person to perform a series of actions: "Take this mall and grip it as I do; so! and now push for the plain and leaning well over thy horse drive the ball with all thy might until thy palm be moist and thy body perspire: then the medicine will penetrate through thy palm and will permeate thy person. When thou hast done with playing and thou feelest the effects of the medicine, return to thy palace, and make the Ghusl ablation in the Hammam bath, and lay thee down to sleep; so shalt thou be come whole; and now peace be with thee!" (The Tale of the Wazir and the Sage Duban) [2]). Sometimes unusual ingredients are required to concoct a cure: "The black tom cat which is with him in the oratory hath, on the end of his tail, a white spot, the size of a dirham; let him pluck seven white hairs from the spot, then let him fumigate her therewith and the Marid will flee from her and not return; so she shall be sane for the rest of her life." (The Tale of the Envier and the Envied) [2].

In Abubakar Imam's story the cure for the diseased prince - the water of cure - is a magical potion. It is also peculiar that the important part of the plot is about how the water is sought after and finally obtained. The motifs of a lengthy quest, various obstacles and ordeals that the protagonist overcomes, and finding of the cure, are absent from Arabic folklore. This combination of motifs is present in the Brothers Grimm's "Water of Life" [3]: the King's sons embark upon a journey with the purpose of finding the magical cure to treat their father's condition. The progress of the protagonists and their finding of the water of life are among the most important elements of the plot. The storyline featured in the book by Abubakar Imam is likewise based on such patterns.

The composition of «The Water of Cure» may be divided into two parts, that is the introduction and the main body of the text. The introductive part is written in a third person. The main body of the text is the firs-person narrative in form of a life story.

The introductive part provides a characterisation of the protagonist, describing him as being wealthy and influential. The transition to the main body of the text is the promise by the protagonist to relate the story of how he had obtained his riches.

In the story, which the protagonist tells about his life, and the adventure that had befallen him, initially two principal tasks are formulated:

1. The protagonist must avenge the death of his father - this idea follows from the prophecy.

2. The protagonist should prove veracity of his adoptive father's words, informing the king of the existence of magical water, which could heal the king's son. If the hero obtained this water of life, he would then have done something that no one before him had been able to achieve.

The main body of the book describes the quest for the water of life and realisation of revenge. That part of the text consists of a number of related anecdotal stories, mainly based on Hausa folklore motifs. The anecdotes contained in the narrative can be subdivided into the following groups: the stories about vituperative and stupid wives, the stories about thieves, and the stories about the artful dodger.

In the cycle of stories about the latter, various stereotypical oppositions can be discerned, such as: 


\begin{tabular}{|l|l|}
\hline The oppositions contained in Hausa anecdotal tales & Their transformation in «The Water of Cure» \\
\hline A pagan - a malam (religious) & The protagonist - Malam Zurke \\
\hline Hausa - Fulbe (ethnic) & The protagonist - the Fulbe \\
\hline An urban dodger - a rustic simpleton & The protagonist - a country cousin (Zurke) \\
\hline
\end{tabular}

One episode of "The Water of Cure" deserves additional mentioning: in this fragment the protagonist pretends to be a saint and succeeds in working a miracle. In this case, the author refers to the stories about Usman dan Fodio and the stories describing miracles he had been able to accomplish. The episode about Alhaji's miracle is an adaptation of the story about how Usman dan Fodio was able to instantly transport himself from one location to another, usually rather remote. Alhaji, the main protagonist of "The Water of Cure" uses his cunning nature to deceive people into believing that he can miraculously move from one place to another and so acquires the status of a saint.

The author's treatment and development of Hausa anecdotal tales can be revealed primarily in two aspects: firstly, it is appearance of the author's digressions and deliberations, and, secondly, explanations of the tricks and pranks, which the protagonist performs. The story of Alhaji and a village boy can serve as an example. The plot is typical for Hausa folklore: a cunning hero deceitfully acquires the money which belongs to a village simpleton [4]. The characters arrive to a judge's house in order to clarify which one of them is in the right. A cunning man enumerates his "witnesses" in court mentioning imaginary people: Malam Whole, Malam Halfling, and Malam Quarterling. Indeed, the protagonist is speaking figuratively of the money he is thus promising to the judge as a bribe. Alhaji's behaviour, the manner in which he disentangles himself from a trying and arduous situation is based on a play on words, a linguistic ruse, which is rather widely distributed in anecdotal tales with pagans in the role of protagonist. The difference of literary plot to those of fairy tales is, however, that the author explains the nature of the trick and comments on the judge's behaviour: "Two coins each worth two shillings I referred to as Malam Doubling and his brother, the coin worth a shilling I mentioned as Malam Whole, the coin worth a sixpence I described as his brother Halfling, whereas the thruppence was designated as Malam Quarterling. When I mentioned 100 other witnesses who would arrive at midnight, what I meant was 100 shillings. This was my way of letting the judge know that by midnight I would bring him 105 shillings and nine pence if he resolves the matter in my favour - alas, this is the kind of time which we are living through now. The golden rule is that whoever has the gold makes the rules" [1, p.18].

The stories which the author includes into this part of the book have various natures and functions:

1. Stories of the protagonist's coming into wealth: of acquiring creature comforts, respect on the part of the powers that be, marriage to a beautiful lady Jamilatu (whose name means "A beautiful one»); these include stories of Alhaji's coming victorious over the tallest man, etc. The protagonist's marriage here comes to be understood as one attribute of his heroic image. Subsequently Alhaji leaves his wife in her native town together with his entire possessions acquired previously and does not come to recover them until much later. In such narratives his antagonists are: Malam Zurke, a wealthy man from Syria, Jamilatu's suitors, an Englishman, etc. Alhaji uses deceit to gain those people's possessions for himself. 
2. Stories about the protagonist falling into difficult situations and his successful disentanglement from those: cf. tales about a rabid camel, a vituperative woman, a cuckold husband, an unlucky thief. There is no gain to be acquired by the hero himself. Adverse circumstances or people's scheming compel him to seek solutions for unanticipated problems. It is rather curious that the most prominent character in the two stories is not Alhaji but a secondary figure called Zurke (these are the stories about his foul-mouthed lady wife, as well as about Zurke and a thief).

The narration describing travels and adventure of Alhaji is also enclosed in a certain frame. The beginning of his quest is marked by a meeting with an old man who confirms to him that water of cure exists. The end of the search is the arrival in Jerusalem. Here the protagonists decides to change his behaviour, to alter his ways, whereby the author concludes the anecdotal part of his story. It is there also that the protagonist learns where the water of cure is located. In the beginning, the middle, and the end of the search we witness 3 episodes borrowed from non-Hausa, most probably Arabic, folklore. There the protagonist comes across his aides: the old renunciate, the old man from Nasarava, and the old man from Jerusalem. In each case an explanation is given as to why the protagonist is being assisted. The motivation is strictly observed:

1. The help on the part of the old renunciate is due to a degree of kinship, i.e. the protagonist happens to be his nephew.

2. The assistance rendered by the old man from Nasarava is logical within the framework of serving the Emir, in front of whom the protagonist feigns his sainthood.

3. The intercession by the old man from Jerusalem is explained through a service to the Emir with whom the protagonists had stayed.

The episode of the protagonists sojourn in Jerusalem marks, as it has already been said, the end of the quest for the magical water. The anecdotal part of the story is followed by a part developed, apparently, through the influence of Arabic folklore, - the next part of the protagonist's progress can be called the narrative of procuring the water or cure. Assisted by a genie, who happens to be a slave to a sword which Alhaji had discovered, the protagonist is transferred to the country of genies, where he acquires a new assistant - the Emir of the genies. The genie's help is likewise motivated. This episode is approached by the author using all manner of logical connections. The instruments of motivation are also two stories adduced at this point by Abubakar Imam. The first story relates a case where Sakimu (the murderer of the protagonist's father) incidentally kills the genie's son. Thus, having put the end to Sakimu, the protagonist avenges not only his father but also the genie's little son. It is possible that the whole story stems from European folklore. This is the story about a woman giving water to the Emir of the genies, when he was but a little child, and subsequently quenching thirst also of his mother. The woman had no knowledge of those creatures being genies. The kind woman was the mother of Alhajis stepfather, and it was since that time that a family friendship had been struck. The old genie considers the Imam, Alhaji's stepfather, his junior brother; the existence of the familial relation becomes a significant cause to help the protagonist. This assistance is not rendered as a reward obtained as a result of an ordeal, which is a specific feature particular to a novella-type tale (cf. [5]).

Procuring the water of cure happens to be a trying matter. The protagonist does not adhere to any magical media whilst doing so. Alhaji must perform certain actions (enter 
through a special door, not look back on the way, etc.) in a specific order. Concluding the ordeal in the right way becomes possible only at his second attempt. This particular part is concluded with the protagonist receiving a magical signet ring from the ruler of the genies.

Saying farewell to the old Genie marks the transition of the protagonist from the world of the genies to that of people. Having procured the magical water, the protagonist now faces the task of returning home. Here we come across detailed descriptions of the ordeals with which Alhaji must further cope upon his return to the people's world. Ignorant Christians who shy away from and despise everything they do not understand refuse to help the protagonist: "This man said he would not speak to me until I had gone and washed myself. The man had apparently decided that the darkness of my skin was due to it being dirty. He was ignorant of the fact that there exist people for whom such skin colour is typical. I also asked the others to take me, but they all turned me down. They chased me away saying I smelled bad and that they were afraid I would infect them with lice" [1, p.50-51].

Typical element for Arabic folklore is that for many a day the hero is impelled to sail in a rickety boat at the mercy of the waves - emaciated, famished and sick, and thereafter rescued by local people. Another traditional feature of Arabic folklore is a happy reunion of the hero with his family.

As it was mentioned already, one of the sources for "The Water of Cure" was a collection of Arabic folklore. A study of the structure of "The Water of Cure" strongly suggests that certain elements and motifs are borrowed from "Arabian Nights» (slave of the sword, etc.). An example thereof is the story of finding the magical cave. The episode in question obviously consists of separate motifs stemming, in all probability, from "Ali-Baba and the Forty Thieves":

\begin{tabular}{|c|c|c|}
\hline Motifs & A Ali-Baba and the Forty Thieves [6] & B The Water of Cure $[1, \mathrm{p} .44-45]$ \\
\hline $\begin{array}{l}\text { Appearance of forces } \\
\text { inimical to the hero. }\end{array}$ & $\begin{array}{l}\text {..suddenly he espied a dust-cloud spireing } \\
\text { high in air to his right and moving rapidly } \\
\text { towards him; and when he closely consid- } \\
\text { ered it he descried a troop of horsemen } \\
\text { riding on amain and about to reach him. }\end{array}$ & $\begin{array}{l}\text {...After a while he saw a pair of fly- } \\
\text { ing genies }\end{array}$ \\
\hline $\begin{array}{l}\text { B The manifested } \\
\text { beings convey a load. }\end{array}$ & & who were carrying a man. \\
\hline $\begin{array}{l}\text { A The hero conceals } \\
\text { his presence. }\end{array}$ & $\begin{array}{l}\text { At this sight he was sore alarmed, and } \\
\text { fearing lest perchance they were a band of } \\
\text { bandits who would slay him and drive off } \\
\text { his donkeys, in his affright he began to run; } \\
\text { but forasmuch as they were near hand and } \\
\text { he could not escape from out the forest, he } \\
\text { drove his animals laden with the fuel into } \\
\text { a bye-way of the bushes and swarmed up a } \\
\text { thick trunk of a huge tree to hide himself } \\
\text { therein; and he sat upon a branch whence } \\
\text { he could descry everything beneath him } \\
\text { whilst none below could catch a glimpse of } \\
\text { him above; and that tree grew close beside } \\
\text { a rock which towered high above-head. }\end{array}$ & \\
\hline
\end{tabular}




\begin{tabular}{|c|c|c|}
\hline Motifs & A Ali-Baba and the Forty Thieves [6] & B The Water of Cure $[1, \mathrm{p} .44-45]$ \\
\hline $\begin{array}{l}\text { A The manifested } \\
\text { beings convey a load. }\end{array}$ & $\begin{array}{l}\text { Ali Baba saw the robbers, as soon as they } \\
\text { came under the tree, each unbridle his } \\
\text { horse and hobble it; then all took off their } \\
\text { saddle-bags which proved to be full of } \\
\text { gold and silver. }\end{array}$ & \\
\hline $\begin{array}{l}\text { Discovery of the secret } \\
\text { place. }\end{array}$ & $\begin{array}{l}\text { The man who seemed to be the captain } \\
\text { presently pushed forwards, load on shoul- } \\
\text { der, through thorns and thickets, till he } \\
\text { came up to a certain spot }\end{array}$ & $\begin{array}{l}\text { They landed not far from me and } \\
\text { quickly dug a round hole in the earth. }\end{array}$ \\
\hline $\begin{array}{l}\text { Opening of the secret } \\
\text { door. }\end{array}$ & $\begin{array}{l}\text { where he uttered these strange words, } \\
\text { "Open, O Simsim I» and forthwith ap- } \\
\text { peared a wide doorway in the face of the } \\
\text { rock. }\end{array}$ & $\begin{array}{l}\text { Then I heard one of the genies saying: } \\
\text { - Obey the words of Suleiman, son of } \\
\text { David, display the leaves of your gate! } \\
\text { The earth opened }\end{array}$ \\
\hline $\begin{array}{l}\text { Admission of beings } \\
\text { carrying the load } \\
\text { inside the shelter. }\end{array}$ & $\begin{array}{l}\text { The robbers went in and last of all their } \\
\text { Chief and then the portal shut of itself. }\end{array}$ & $\begin{array}{l}\text { and the genies dragged the man in- } \\
\text { side the crevice.... }\end{array}$ \\
\hline $\begin{array}{l}\text { B The hero conceals } \\
\text { his presence. }\end{array}$ & & $\begin{array}{l}\text { I ... resolved to hide, so that they } \\
\text { would not be able to see me. So I bur- } \\
\text { ied myself in the sand so that even my } \\
\text { head was concealed... }\end{array}$ \\
\hline $\begin{array}{l}\text { Reappearance of } \\
\text { beings from the } \\
\text { shelter. }\end{array}$ & $\begin{array}{l}\text {...suddenly the portal flew open. The } \\
\text { robber-chief was first to issue forth; then, } \\
\text { standing at the entrance, he saw and } \\
\text { counted his men as they came out... }\end{array}$ & The genies left.... \\
\hline $\begin{array}{l}\text { Departure of inimical } \\
\text { forces. }\end{array}$ & $\begin{array}{l}\text {... each slung on his saddle-bags and bri- } \\
\text { dled his own horse and as soon as ready } \\
\text { they rode off, led by the leader, in the di- } \\
\text { rection whence they came. }\end{array}$ & A soon as the genies had gone, \\
\hline $\begin{array}{l}\text { The hero leaves the } \\
\text { shelter. }\end{array}$ & $\begin{array}{l}\text { Then he thought within himself, «I too } \\
\text { will try the virtue of those magical words } \\
\text { and see if at my bidding the door will } \\
\text { open and close.» }\end{array}$ & I crawled outside \\
\hline $\begin{array}{l}\text { Usage of a magical } \\
\text { formula to open the } \\
\text { cache of the inimical } \\
\text { forces. }\end{array}$ & $\begin{array}{l}\text { So he called out aloud, «Open, O Sim- } \\
\text { sim!» }\end{array}$ & $\begin{array}{l}\text { And went to the place where the } \\
\text { earth had opened, ..., and said: } \\
\text { - Obey the words of Suleiman, son of } \\
\text { David, display the leaves of your gate! }\end{array}$ \\
\hline $\begin{array}{l}\text { The hero enters the } \\
\text { shelter. }\end{array}$ & $\begin{array}{l}\text { And no sooner had he spoken than } \\
\text { straightway the portal flew open and he } \\
\text { entered within. }\end{array}$ & $\begin{array}{l}\text { A door opened in the earth. I peeked } \\
\text { inside, and then I entered. }\end{array}$ \\
\hline
\end{tabular}

«The Water of Cure» presents emergence of the hero from the underground using the elements from "Aladdin; or the Magical Lamp" [7]. In a way similar to Arabic text, Abubakar Imam uses the motif of a supernatural assistance appearing in consequence of discovering a magical object: 


\begin{tabular}{|l|l|}
\hline \multicolumn{1}{|c|}{ Aladdin; or the Magical Lamp [7, p. 22-23] } & \multicolumn{1}{|c|}{ The Water of Cure [1, p.45-46] } \\
\hline $\begin{array}{l}\text { In this action of joining his hands, he happened, without } \\
\text { at all thinking of it, to rub the ring... Upon its being thus } \\
\text { rubbed, a Genie of a most enormous figure and most hor- } \\
\text { rid countenance, instantly rose, as it were, out of the earth } \\
\text { before him... }\end{array}$ & $\begin{array}{l}\text { Then I took a cloth and decided to wipe the } \\
\text { sword. However, no sooner had I touched } \\
\text { the blade, than a genie manifested in front } \\
\text { of me }\end{array}$ \\
\hline $\begin{array}{l}\text { And he addressed these words to Aladdin: "What do you } \\
\text { wish? I am ready to obey you as your slave; as the slave of } \\
\text { him who has the ring on his finger..." }\end{array}$ & $\begin{array}{l}\text { And proclaimed: } \\
- \text { O, my lord, what will be your wish! }\end{array}$ \\
\hline $\begin{array}{l}\text { At any other moment, and on any other occasion, Aladdin, } \\
\text { who was totally unaccustomed to such appearances, would } \\
\text { have been so frightened at the sight of such a wonderful fig- } \\
\text { ure, he would have been unable to speak; }\end{array}$ & $\begin{array}{l}\text { In horror, I threw the sword away and cov- } \\
\text { ered my face with my hands, about to im- } \\
\text { plore the genie not to torture me but to put } \\
\text { me to death immediately ... }\end{array}$ \\
\hline $\begin{array}{l}\text { but he was so entirely pre-occupied with the danger and peril } \\
\text { of his situation, that h answered without the least hesitation: } \\
\text { "Whoever you are, take me, if you are able, out of this place." }\end{array}$ & $\begin{array}{l}\text {..My heart started beating with joy and I } \\
\text { said: } \\
\text { - If this be as you say it is, then take me } \\
\text { to a place where I can find the water of life. }\end{array}$ \\
\hline
\end{tabular}

The author uses expressive means of Arabic folklore in a rather selective manner. Heightened emotions and ornate expressions which are so particular to Arabic narrative are absent in Hausa prosaic oral tradition. Intense imagery, as well as development of descriptions as an artistic device find the embodiment in Hausa poetic genres, whereas for prosaic narrative the eventful aspect is more important. In "The Water of Cure" only when the prodigal son rejoins his parents after a lengthy absence does the author allow a touch of emotion, not surprisingly the description of situation is given in Arabic narrative style: "He rushed to me with open arms. We both shed tears out of joy. Having entered the house, I saw my elderly mother, we embraced each other, our minds were ravished away with happiness and we fainted. Thereafter they sprinkled us with water and we recovered our senses." [1, p. 53].

Discussing the adoption by Hausa author of Arabic fairy tale elements and artistically treated plots of Hausa anecdotal tales, it is necessary to point out that the text in question was also affected by European folklore. For instance, one episode describes Alhaji's encounter with a giant Zandoro. Alhaji must also touch the head of the giant, or be killed in case of failure to do so. The protagonist succeeds in outwitting the giant in the following manner: Alhaji says that a wall in his room is splitting open and so he is making it whole again with a needle and some string. The protagonist invites Zandoro to take a look into his room in order to see how the work is being done. As soon as the giant sticks his head through the window, Alhaji succeeds in touching his head. It is notable that in the episode just described Alhaji calls sewing his occupation. This detail points to an influence of the brothers Grimm fairy tale "The Valiant Little Tailor" in which the tailor protagonist likewise outsmarts a giant.

An inseparable part of «The Water of Cure» constitute elements of didactics and aetiology. Abubakar Imam employs a personal touch in his didactics. In folklore, "sayings and adages imply their universal meaningfulness and recognition. Having been used in a context of a folk fairy tale novella, they acquire, as it were, a character of uniqueness and singularity which is alien to their nature. They appear to be products of individual wit and 
ingenuity" [5, p. 151]. In the literary work which is the subject of our attention didactic asides express folk wisdom: "... Never have I forgotten that a respectable man always repays the offender for the evil which had been caused." [1, p. 51]; "...Whatever will be, will be. At any rate the winner will be alive in the coming year." [1, p. 23]; "Should you want to conceal your disgrace, cover it with a straw mat of madness." [1, p. 27]; "Alas, whatever has been gained dishonestly will not stand you in good stead" [1, p.38]; "A theft in a thief's house is a good thing" [1, p. 41].

The didactic theme is continued also by extended asides (deliberations and commentaries of the protagonist), for example: "when a man is enraged it is useless to reason with him. You talk to him, yet he grows ever so wilder. The best would be to sit him down in the shade and keep silence until his anger has subsided" [1, p. 29].

Aetiological elements can also be traced in the narrative about the water of life. There is a story about where this water can be found and why it is out of reach of people, and also a story that tells us how the protagonist had accidentally spilt the larger portion of the magical water and it got spread throughout the Hausa country imparting its magical power to all Hausa medicine.

Time in "The Water of Cure" does not present a historical outline, which feature is likewise typical for fairy tale folklore, although it is not uncommon that certain figures of European origin appear in the text thus indirectly imbuing it with a certain degree of historicity. "The Water of Cure" is divided into meaningful parts which span certain stages in the life of the protagonist: portraying him in his old age (rich and respectable), the history which precedes his birth, his childhood (careless and unwilling to learn), his youth and coming of age.

Like time, place also changes dynamically depending on the purposes of the writer. The text features certain areas of the world: 1) the realm of genies and water people; 2) the realm of humans. In the plot of the book the latter is predominant. The protagonist departs on his journeys from the city of Kontagora, possibly for the reason that it was the native city of the author. The protagonist roams throughout Nigeria and then also traverses its borders. Nonetheless, despite the fact that the protagonist travels to various cities of the world (for example, Jerusalem), their poor descriptions reflect mainly reality of the Hausa country. The protagonist's travels are subdivided into a number of shorter episodes which possess identical structure: arrival to a certain place (not necessarily a city) - adventure - departure. The realm of genies is described similarly to the realm of humans. Apparently, the ideas which the Hausa have of the realm of Genies is formed to a large degree by their apprehension of their own reality. The genies themselves resemble people. Genies are as vulnerable as humans, a genie child can be murdered by a common human, genies live in their own country ruled over by a king; like people they also have families and children. They are not entirely devoid of the notions of kindness and altruism: assistance, which once was given by genies to a woman in the human realm, grows into a friendship and even kinship between genies and a human family.

\section{The Characters in «The Water of Cure»}

Considering the nature of the main protagonist in the «The Water of Cure» it is necessary yet again to point out the influence which was rendered on the writings of Alhaji Abubakar Imam by Hausa anecdotal tales. A number of these anecdotal tales describe 
various cunning people (pagans and thieves) as protagonists. The main hero in «The Water of Cure» is a cunning and witty person whose behaviour is not always marked by propriety as concerns the ethics of Islam. In the end of the story Abubakar Imam unexpectedly introduces into his text an element of moral judgement on the behaviour of his sly protagonist, which breaks the laws of the narrative typical for anecdotal tales which he had used in the main body of the text. The author transfers the artful dodger of the fairy tale whose behaviour in folklore normally stands outside moral considerations, into the realm of common morals and propriety. In the end, calling the behaviour of his central character "sinful" Abubakar Imam actually condemns the positive hero he had created in the anecdotal part of his narrative as being a negative one and later reinstates him in the positive status: "I had collected 70 elderly malams, built them a house, and now they all sitting there praying on my account for the sins I had committed whilst roaming the world" [1, p.41].

The narrative is based on the following character oppositions:

\section{Alhaji - Sakimu}

The personality and behaviour of Sakimu are marked as unequivocally negative: he is ungrateful, greedy, treacherous, a murderer of the man who had become his father, etc. He is highly unscrupulous when the matter is all about his gain. Likewise, Alhaji also strives to have his way by any means, however, his actions and their consequence are never taken seriously, indeed Alhaji himself refers to them largely as pranks, or tricks. These two characters are irreconcilably antagonistic.

Alhaji - Zurke

Various characters arise as antagonistic to Alhaji in his quest for the magical water, however the opposition Alhaji - Zurke is persistent throughout the whole narrative. Zurke's personality is not so straightforward. He appears in the very first anecdotal stories normally acting as Alhaji's antagonist. And subsequently their meetings are becoming regular. However, as the plot evolves, the two men become friends: Alhaji for example assists in taming Zurke's vituperative wife, and in the end of the story shares with him his wealth. The author even tells two independent stories about Zurke, in which the latter assumes the role of a protagonist, rather than an antagonist. Antagonism of the two men has the nature of competition, in which Alhaji almost always comes victorious. In this respect, the character of Zurke serves as a kind of background against which the character of Alhaji is getting more clearly visible. The main protagonist comes through as heavier, loftier, when he successfully deceives not only common people (such as rich men, English men, etc.) but also has the upper hand over as cunning an individual as himself.

The personalities of the two main characters - Alhaji and Zurke - are not complete in themselves, as each separate episode features its own image, which is often significantly different to the image the same character was accorded in a previous or a subsequent story. If the nature of the main protagonist, despite certain variations, is more or less consistent and fits appropriately into various combinations typical for household tales relating adventures of crafty and cunning individuals, the character of Zurke is always contradictory. In one of the first stories about Alhaji and Zurke the characters are radically contrasted as respectively "a learned man" and "a village simpleton". The status of a gullible country bumpkin is definitely irreconcilable with the image of Zurke when he is portrayed as 
a knavish and crafty, thieving rogue later in the tale. It is necessary therefore to distinguish the behaviour of the protagonist who in order to secure his gain assumes variable guises - a malam (Alhaji), a saint (Alhaji), a thief (Zurke), from that of the antagonist (Zurke), when his actions are subordinated to the role he plays within a particular plot: a malam, a village simpleton, etc.

It becomes relevant, therefore, to speak more of the roles (functions) of the characters, rather than of the characters as such.

\section{Defining the genre of «The Water of Cure»}

Concerning its genre, the book "The Water of Cure" can be placed somewhere in between popular Arab epic (sira), fairy tale and a picaresque novella (makama).

Traditionally, the biographical genre called sira portrays an epic protagonist. Significant book, which transcends the boundary of a classical sira, is "The Life story of Ali al-Zibaq of Egypt". As in "The Water of Cure» the protagonist here is an artful and crafty man, and it is those qualities that change the entire character of the book: "If in epic novels ... accomplishments of the central character follow in close succession, the story of Ali Zibaq features the succession of his innumerable pranks, the characters competing not so much in strength or courage, as they do in astuteness and artifice. That way, fragmentary adventures of devious characters amalgamate into a kind of a prototype picaresque novel with a single protagonist and more or less unified storyline" [8, p.664]. The narrative of Alhaji is likewise constructed based on the central character's lifestory.

One of the major oppositions in «The Water of Cure», Alhaji - Zurke, has the identified literary source. According to the testimony of the author himself he had transferred into his book two major characters of the makamas of al-Hariri: the prototype for Alhaji was Abu Zayd, whereas Zurke had been modelled on al-Haris ibn Hammam [9, p. 24]. The character of Zurke in many ways does not resemble his prototype, because as we are told by the author himself, Zurke was copied from a real person, one of those street performers who act out various humorous, variety and comedy sketches in Hausa marketplaces 'yan kama. These 'yan kama (literary, "catchers" - so called for their ability to employ their mouths to catch coins thrown to them by people from the audience) have a special place in Hausa culture. Comedy folklore is able to "demean" the authority of "lofty" topics and genres, related first and foremost to religious literature. In order to achieve that, a combination technique of intertwining the "lofty" and the "vulgar" themes is used: "separate parts of the lofty or elevated formulas are substituted with every-day, household, and, most frequently, kitchen-related details, as well as with all manner of rubbish» [10, p. 143]. As Shcheglov states, "apart from purely artistic activity other ways to belittle a lofty topic included theatrical pranks featuring travesty, drag and impersonation" [10, p. 142].

Obviously the makama genre significantly underpins the writing of Abubakar Imam. The picaresque novellas penned by al-Hariri, with which Abubakar was familiar, shape the anecdotal part of the book, which the author heavily imbued with national content. The specificity of makamas is that they consist of a sequence of novellas linked by single or several characters. Their central personages are often smart alecs and double crossers. According to Fil'shtinsky, while other poetic and prosaic genres of mediaeval Arab literature have parallels in other contemporaneous cultures, the genre of makamas is quintessentially Arabic. Conventionally, based on purely outer parameters, this genre can be associated 
with the picaresque novella of Europe. "All [in the "higher society"] enjoyed funny pranks of thief's and vagabonds, their roguish swagger, insolence, flippancy, and argot with which they ornately «beautified» their speech" [8, p. 279]. As stated by Fil'shtinsky, the thematic set of makamas and their plots were of secondary importance and had been based on a relatively limited circle of themes and situations. Their main aesthetic criterion was the beauty and wit of their language. "It was an art form intended for a narrow circle of people who were able to decipher the virtually uninterrupted stream of metaphors, similes, circumlocutions, and puns, as well as to perceive ideas, masterfully laced with wordplay and obscure allusions. Linguistic ornamentation and stylistic quirks in that type of prose possessed self-sufficiency and on many occasions the excesses of style and the wish to accumulate as many effects as possible completely adumbrated the plot" [8, p.276].

As has been already mentioned, the protagonist and antagonist in "The Water of Cure" have their origins in the characters of makamas authored by al-Hariri. Abubakar Imam uses main features of the Arab characters respectively. Alhaji and Zurke, similar to Abu Zayd, reappear in "different places always in a new guise" and display "in their actions wit and ingenuity" [8, p.304]. In the words of Fil'shtinsky, the image of the central character of the makamas by al-Hariri possesses certain features of Juha, the hero of national Arabic yarns.

Like al-Hariri before him, the author of "The Water of Cure" places the main stress on portrayal of the comic ruses and pranks played by his protagonists. However, in many episodes the main feature of the makamas is missing, namely their common way of letting the central character display his own poetic improvisations, and lexical virtuosity irrespective of his outer appearance or a prank he has just played.

In terms of composition, Abubakar Imam's work is also similar to the makamas by alHariri. Multiple stories from «The Water of Cure» display analogous sequence of events: meeting of the characters, their recognition of each other, and subsequent parting. Like in the makamas, the tales in "The Water of Cure" are all organized into a single line, however the action in them does not move along a rising curve but rather along a circle within the confines of a single plane. The transition from one episode to another is fixed by an outer space factor, such as a change of cities in which events unfold, whereas time carries little to no meaning, is rhythmically repeated and affects neither the protagonists nor the outer appearance of the characters [8, p.307].

Conclusive part of «The Water of Cure» also displays the influence of al-Hariris makamas. Alhaji, similar to Abu Zayd, repents: "a vagabond devoid of finesse becomes a virtuous ascetic" [8, p. 308]. In the oeuvre of al-Hariri the didactic element is revealed in accordance with the canons prevalent in Arabic literature. Following in the footsteps of the Arab author, Abubakar Imam imparts to his book a certain didactic flair.

It is not only the absence of stylistic embellishments and linguistic virtuosity that makes «The Water of Cure» different from the makamas of al-Hariri. In all novellas of the Arab author main characters al-Haris ibn Hammam and Abu Zayd have arguments on various topics, such as a discourse on whom a man should marry - a girl or a widow or an argument about who is superior - a chancery officer or a revenue service official. In the words of Fil'shtinsky, "At all times Abu Zayd ... is having an argument with himself and, having posited a statement is hasty to prove it wrong with his own words or actions... This is an embodiment of ... a contradictory attitude to life, ... a distinctly expressed understanding of compatibility of various outlooks and acceptability of a dualistic attitude to 
events and ideas" [8, p. 310]. «The Water of Cure» is devoid of any such philosophical arguments or deliberations. Nonetheless, as I endeavoured to demonstrate in the process of the above study, Alhaji Abubakar Imam reveals, as does the Arab author, multiple aspects of everyday life of the Hausa people.

\section{References}

1. Alhaji Abubakar Imam. Ruwan Bagaja. Zaria, Northern Nigerian Publishing Company, 1934. Available at: www.gumel.com (accessed: 11.10.2016).

2. The book of the thousand nights and a night. A Plain and Literal Translation of the Arabian Nights Entertainments. Translated and annotated by Richard F. Burton. Australia, University of Adelaide. Available at: https://ebooks.adelaide.edu.au/b/burton/richard/b97b/complete.html\#section841 (accessed: 11.09.2016).

3. Grimm J., Grimm W. Fairy Tales of the Brothers Grimm. Translated by E. Taylor. The Floating Press, 2009. $453 \mathrm{p}$.

4. Edgar F. Littafi na Tatsuniyoyi na Hausa [A book of Hausa tales]. Edinburgh, 3 vol., Belfast, 19111913. (In Hausa)

5. Meletinsky E. M. Istoricheskaya poetika novelly [Historical poetics of the novella]. Moscow, Nauka Publ., 1990. 275 p. (In Russian)

6. Ali Baba and the Forty Thieves. Translated by Richard F. Burton. Ali Baba and the Forty Thieves from the 1001 Nights. Edited by D.L. Ashliman. Available at: https://www.pitt.edu/ dash/alibaba.html\#burton (accessed: 18.09.2016).

7. Aladdin; or the Magical Lamp. Lawrence Lovechild. Davis, Porter \& Company, 1846. 118 p.

8. Fil'shtinsky I. M. Istoriya arabskoi literatury $v$ X-XVIII $v v$. [The History of Arabic Literature in $10-13^{\text {th }}$ centuries]. Moscow, Nauka Publ., 1991. 726 p. (In Russian)

9. Furniss G. Poetry, prose and popular culture in Hausa. Edinburgh, Edinburgh University Press for the International African Institute, 1996. 338 p.

10. Shcheglov Yu. K. Sovremennaya literatura na yazikah Tropicheskoi Afriki [Contemporary Literatures in the Languages of Tropical Africa]. Moscow, Nauka Publ., 1976. 247 p. (In Russian)

Received: 10.08.2017

Accepted: 06.12.2017

Author's information:

Lyakhovich Anastasia V. — PhD; anastasia_07007@mail.ru

\section{“Живая вода” Альхаджи Абубакара Имама как пример ранней художественной прозы на языке хауса (Нигерия)}

\section{А. В. Ляхович}

Санкт-Петербургский государственный университет,

Российская Федерация, 199034, Санкт-Петербург, Университетская наб., 7-9

Для цитирования: Lyakhovich A. V. “The Water of Cure” by Alhaji Abubakar Imam as an example of Hausa early fiction // Вестник СПбГУ. Востоковедение и африканистика. 2018. Т. 10. Вып.1. C. 104-117. https://doi.org/10.21638/11701/spbu13.2018.109

Тридцатые годы XX века - знаковый период в истории нигерийской литературы на языке хауса. Именно в это время зарождаются предпосылки для формирования новой для хауса формы творчества - художественной прозы. В статье дается анализ одного из первых художественных произведений на языке хауса, «Живая вода», написанных 
в 1930-х годах. Описаны жанрово-композиционные особенности сочинения, рассмотрены образы героев. В заключении определяется жанровая специфика произведения. Ключевые слова: художественная литература, Северная Нигерия, Живая вода, Альхаджи Абубакар Имам.

Контактная информация:

Ляхович Анастасия Викторовна — канд. филол. наук; anastasia_07007@mail.ru 